Journal of Clinical Investigation
Vol. 44, No. 12, 1965

\title{
Abnormalities in Carbohydrate Tolerance Associated with Elevated Plasma Nonesterified Fatty Acids *
}

\author{
Don S. Schalch † ANd David M. Kipnis $\ddagger$ \\ (From the Division of Metabolism, Department of Medicine, Washington University School of \\ Medicine, St. Louis, Mo.)
}

Several abnormalities of carbohydrate metabolism common to a variety of endocrine and nutritional disorders have been shown recently to be associated with a high plasma concentration of nonesterified fatty acids (NEFA). For example, starvation or carbohydrate deprivation in the normal individual produces not only a marked impairment of carbohydrate tolerance, but also results in elevated levels of plasma NEFA (1-3). The coincident development of impaired carbohydrate tolerance and decreased sensitivity to insulin in association with elevated fasting plasma NEFA levels is seen in obesity (4-6), maturity-onset diabetes mellitus (7-9), acromegaly $(5,10,11)$, pregnancy $(12,13)$, and subjects given exogenous human growth hormone (14-17). Randle, Garland, Hales, and Newsholme (18) have recently suggested that elevated plasma NEFA levels may be causally related to the impaired carbohydrate tolerance and decreased insulin sensitivity seen in these conditions, and have proposed the term "glucose-fatty-acid cycle" to denote the interactions between glucose and fatty acid metabolism in peripheral tissues responsible for the control of the blood glucose and fatty acid levels.

Considerable evidence from in vitro studies in several laboratories (18-22) can be marshalled in support of this intriguing concept, but to date

* Submitted for publication August 25, 1964 ; accepted September 2, 1965.

Presented in part at the Fifty-sixth Annual Meeting of the American Society for Clinical Investigation, Atlantic City, N. J., May 1964.

This investigation was supported in part by U. S. Public Health Service research grants AM-01921, FR-00036, and FR-44-03.

$\dagger$ U. S. Public Health Service postdoctoral research fellow. Present address: University of Rochester Medical Center, Rochester, N. Y.

$\ddagger$ Address requests for reprints to Dr. David M. Kipnis, Dept. of Internal Medicine, Washington University School of Medicine, St. Louis 10, Mo. there has been no demonstration that the circulating level of plasma NEFA influences either the rate of glucose utilization or the insulin responsiveness of the intact organism. ${ }^{1}$ The present study was undertaken to determine whether an acute and sustained elevation of the plasma nonesterified fatty acid level in man can, in itself, impair carbohydrate tolerance and decrease the sensitivity of the peripheral tissues to insulin.

\section{Methods}

Experimental procedure. A simple experimental technique has been devised that rapidly raises the plasma NEFA level for a prolonged period and does not require the use of either endocrine or nutritional influences, which in themselves impair carbohydrate tolerance. The experimental procedure, hereafter referred to as the fat meal-heparin regimen, is based on the following observations: 1) marked chylomicronemia develops 3 to 5 hours after a fat meal $(23)$; 2) chylomicrons are substrates for tissue lipoprotein lipase (24); and 3) intravenous heparin activates lipoprotein lipase and its release into the circulation $(24,25)$. The fat meal-heparin regimen used in this study consisted of the ingestion of a $60-\mathrm{g}$ fat meal of emulsified corn oil $(60 \mathrm{~g}$ corn oil, $60 \mathrm{ml}$ water, $15 \mathrm{~g}$ egg white, $6 \mathrm{ml}$ vanilla extract, $0.5 \mathrm{~g}$ salt, and $0.4 \mathrm{ml}$ sodium cyclamate) followed in 3 hours by the intravenous administration of $50 \mathrm{mg}$ of heparin sodium.

Twelve normal subjects and five patients with mild diabetes mellitus according to the criteria of Fajans and Conn (26) were studied. None of the diabetic subjects required insulin therapy. Each individual acted as his own control since he was tested after an overnight fast with and without the fat meal-heparin regimen on one or more occasions. All subjects were on diets containing at least $200 \mathrm{~g}$ of carbohydrate for several days before testing. Carbohydrate tolerance was measured with the rapid intravenous glucose tolerance test, i.e., $25 \mathrm{~g}$ glucose intravenously over 4 minutes. The slope of the glucose disappearance curve when plotted as a semilogarithmic function represents the rate of glucose disappearance

1 While this manuscript was in preparation, Felber and Vannotti [Med. exp. (Basel) 1964, 10, 153] published data demonstrating the impairment of glucose tolerance after the intravenous infusion of a fat emulsion. 
NEFA

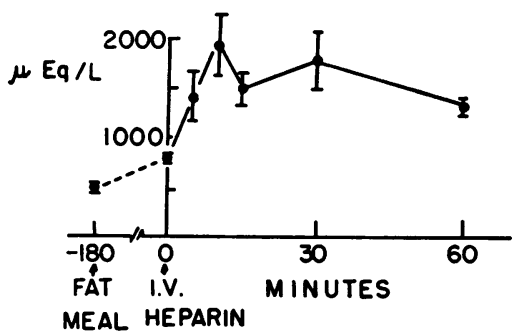

INSULIN

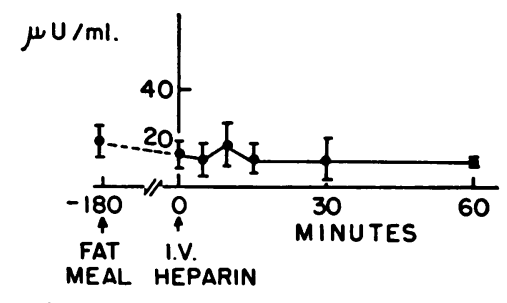

GLUCOSE

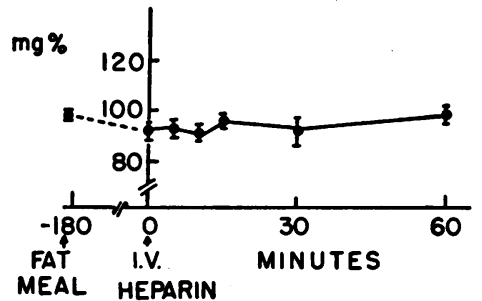

GROWTH HORMONE

$\mathrm{m} \mu \mathrm{g} / \mathrm{ml}$

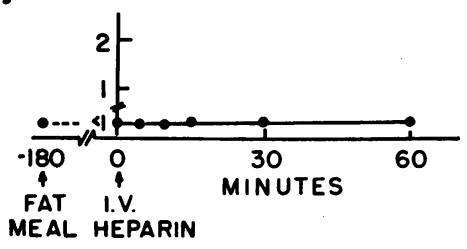

Fig. 1. EFFECT OF THE FAT MEAL-HEPARIN REGIMEN ON PLASMA NONESTERIFIED FATTY ACIDS (NEFA), GLUCOSE, INSULIN, AND GROWTH HORMONE LEVELS IN THREE NORMAL SUBJECTS. Each value represents the mean \pm SEM.

(K) in per cent per minute (27). $\mathrm{K}$ can therefore be determined by the following formula:

$K=\frac{\ln B G_{1}-\ln B G_{2} \times 100}{t_{2}-t_{1}}$, which reduces to

$$
K=\frac{0.693}{t_{1}} \times 100,
$$

where $\mathrm{BG}_{1}=$ blood glucose at time, $\mathrm{BG}_{2}=$ blood glucose at time ${ }_{2}$, and $t_{1}=$ time when $B_{1} / B_{2}=0.5$. To assess the reproducibility of this method, repeat base-line studies were performed on seven normal subjects and showed an average variability of $13 \%$ between duplicate $K$ rate determinations. All subjects were exposed to approximately the same duration of carbohydrate deprivation overnight before the control studies and when tested with the fat meal-heparin regimen. In the fat mealheparin studies, the iv glucose tolerance test was started 15 minutes after the injection of heparin.

Analytical procedures. Glucose was determined in whole blood by the ferricyanide method with an Autoanalyzer, and plasma NEFA was determined by the microcolorimetric method of Duncombe (28) using the Dole extraction procedure (1). Since lipolysis continues in vitro after the intravenous administration of heparin, blood samples were rapidly cooled after collection and centrifuged for 5 minutes at $4^{\circ} \mathrm{C}$, and $0.5 \mathrm{ml}$ of plasma was added immediately to the extraction solution. The validity of this rapid extraction procedure was demon-

CONTROL

FAT MEAL

I.V. HEPARIN

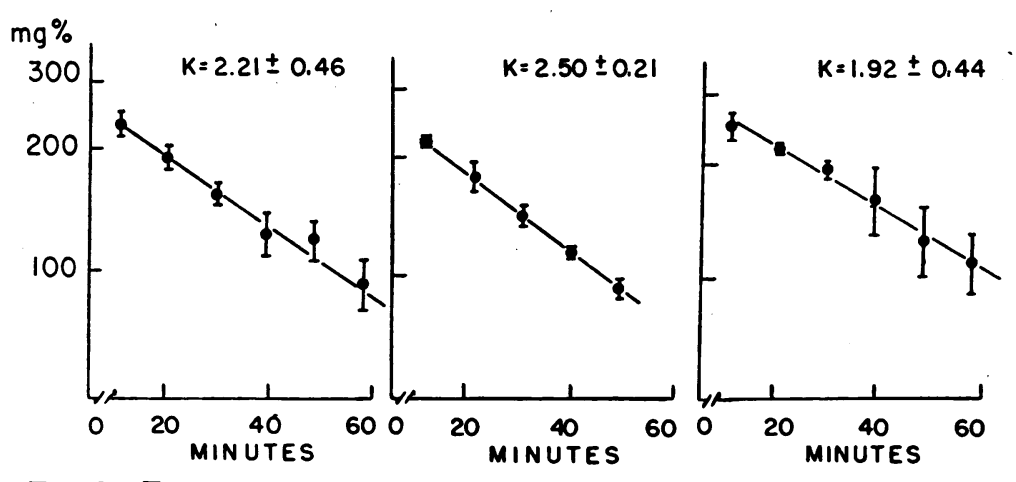

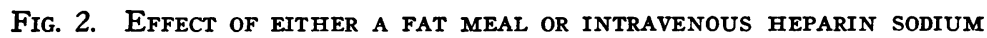
ON GLUCOSE TOLERANCE IN THREE NORMAL SUBJECTS. Each value represents the mean \pm SEM. $K=$ the rate of glucose disappearance. 
TABLE I

Intravenous glucose tolerance

\begin{tabular}{|c|c|c|c|c|c|c|c|c|c|c|c|c|}
\hline \multirow[b]{2}{*}{$\begin{array}{c}\text { Subject } \\
\text { Age, Sex }\end{array}$} & \multirow[b]{2}{*}{ Minutes: } & \multicolumn{11}{|c|}{ Control } \\
\hline & & 0 & 8 & 16 & 24 & 32 & 40 & 48 & 56 & 64 & $t_{3}$ & $\mathrm{~K}_{\mathrm{c}} \dagger$ \\
\hline $\begin{array}{l}\text { G.C. } \\
38 \dot{M}\end{array}$ & $\begin{array}{l}\text { Glucose* } \\
\text { NEFA } \\
\text { Insulin }\end{array}$ & $\begin{array}{r}76 \\
553 \\
9\end{array}$ & $\begin{array}{r}233 \\
753 \\
45\end{array}$ & $\begin{array}{r}214 \\
683 \\
55\end{array}$ & $\begin{array}{l}175 \\
417\end{array}$ & $\begin{array}{r}155 \\
463 \\
42\end{array}$ & $\begin{array}{l}151 \\
465\end{array}$ & $\begin{array}{r}122 \\
622 \\
40\end{array}$ & $\begin{array}{r}121 \\
899 \\
25\end{array}$ & $\begin{array}{r}94 \\
862 \\
37\end{array}$ & $\begin{array}{c}\text { minutes } \\
42\end{array}$ & 1.65 \\
\hline $\begin{array}{l}\text { M.H. } \\
29 \mathrm{M}\end{array}$ & $\begin{array}{l}\text { Glucose } \\
\text { NEFA } \\
\text { Insulin }\end{array}$ & $\begin{array}{r}67 \\
402 \\
8\end{array}$ & $\begin{array}{r}192 \\
697 \\
42\end{array}$ & $\begin{array}{r}95 \\
463 \\
12\end{array}$ & $\begin{array}{r}63 \\
546 \\
16\end{array}$ & $\begin{array}{r}44 \\
398 \\
8\end{array}$ & $\begin{array}{r}42 \\
506 \\
11\end{array}$ & $\begin{array}{r}39 \\
566 \\
9\end{array}$ & $\begin{array}{r}42 \\
480 \\
12\end{array}$ & $\begin{array}{r}48 \\
582 \\
9\end{array}$ & 11 & 6.30 \\
\hline $\begin{array}{l}\text { T.H. } \\
31 \mathrm{M}\end{array}$ & $\begin{array}{l}\text { Glucose } \\
\text { NEFA } \\
\text { Insulin }\end{array}$ & $\begin{array}{r}78 \\
771 \\
12\end{array}$ & $\begin{array}{r}284 \\
817 \\
42\end{array}$ & $\begin{array}{r}147 \\
639 \\
39\end{array}$ & $\begin{array}{r}103 \\
804 \\
32\end{array}$ & $\begin{array}{r}93 \\
543 \\
15\end{array}$ & $\begin{array}{r}84 \\
476 \\
14\end{array}$ & $\begin{array}{r}70 \\
305 \\
17\end{array}$ & $\begin{array}{r}70 \\
530 \\
9\end{array}$ & $\begin{array}{r}64 \\
553 \\
14\end{array}$ & 12 & 5.77 \\
\hline $\begin{array}{l}\text { K.K. } \\
22 \mathrm{~F}\end{array}$ & $\begin{array}{l}\text { Glucose } \\
\text { NEFA } \\
\text { Insulin }\end{array}$ & $\begin{array}{r}88 \\
720 \\
4\end{array}$ & $\begin{array}{r}272 \\
773 \\
30\end{array}$ & $\begin{array}{r}204 \\
490 \\
42\end{array}$ & $\begin{array}{r}170 \\
370 \\
38\end{array}$ & $\begin{array}{r}134 \\
304 \\
36\end{array}$ & $\begin{array}{r}107 \\
331 \\
32\end{array}$ & $\begin{array}{r}83 \\
331 \\
10\end{array}$ & $\begin{array}{r}73 \\
423 \\
9\end{array}$ & $\begin{array}{r}65 \\
330 \\
8\end{array}$ & 22 & 3.15 \\
\hline $\begin{array}{l}\text { G.L. } \\
25 \mathrm{M}\end{array}$ & $\begin{array}{l}\text { Glucose } \\
\text { NEFA } \\
\text { Insulin }\end{array}$ & $\begin{array}{r}88 \\
915 \\
11\end{array}$ & $\begin{array}{r}766 \\
31\end{array}$ & $\begin{array}{r}227 \\
407 \\
38\end{array}$ & $\begin{array}{r}142 \\
412 \\
27\end{array}$ & $\begin{array}{r}128 \\
359 \\
24\end{array}$ & $\begin{array}{r}108 \\
386 \\
23\end{array}$ & $\begin{array}{r}100 \\
476 \\
12\end{array}$ & $\begin{array}{r}92 \\
420 \\
14\end{array}$ & $\begin{array}{r}87 \\
401 \\
19\end{array}$ & 25 & 2.77 \\
\hline $\begin{array}{l}\text { A.N. } \\
28 \mathrm{M}\end{array}$ & $\begin{array}{l}\text { Glucose } \\
\text { NEFA } \\
\text { Insulin }\end{array}$ & $\begin{array}{r}78 \\
673 \\
11\end{array}$ & $\begin{array}{r}194 \\
623 \\
37\end{array}$ & $\begin{array}{r}157 \\
563 \\
15\end{array}$ & $\begin{array}{r}143 \\
531 \\
22\end{array}$ & $\begin{array}{r}118 \\
447 \\
25\end{array}$ & $\begin{array}{r}104 \\
418 \\
14\end{array}$ & $\begin{array}{r}96 \\
265 \\
22\end{array}$ & $\begin{array}{r}90 \\
261 \\
17\end{array}$ & $\begin{array}{r}83 \\
302 \\
19\end{array}$ & 32 & 2.17 \\
\hline$\underset{21}{J} \cdot{ }_{M}$ & $\begin{array}{l}\text { Glucose } \\
\text { NEFA } \\
\text { Insulin }\end{array}$ & $\begin{array}{r}74 \\
617 \\
26\end{array}$ & $\begin{array}{r}213 \\
476 \\
64\end{array}$ & $\begin{array}{r}172 \\
484 \\
33\end{array}$ & $\begin{array}{r}145 \\
471 \\
19\end{array}$ & $\begin{array}{r}97 \\
532 \\
27\end{array}$ & $\begin{array}{r}101 \\
675 \\
11\end{array}$ & $\begin{array}{r}76 \\
487 \\
24\end{array}$ & $\begin{array}{r}80 \\
479 \\
17\end{array}$ & $\begin{array}{r}78 \\
393 \\
17\end{array}$ & 26 & 2.67 \\
\hline $\begin{array}{l}\text { C.R. } \\
38 \mathrm{~F}\end{array}$ & $\begin{array}{l}\text { Glucose } \\
\text { NEFA } \\
\text { Insulin }\end{array}$ & $\begin{array}{r}76 \\
725 \\
4\end{array}$ & $\begin{array}{r}247 \\
770 \\
74\end{array}$ & $\begin{array}{r}148 \\
862 \\
34\end{array}$ & $\begin{array}{r}132 \\
554 \\
36\end{array}$ & $\begin{array}{r}109 \\
431 \\
15\end{array}$ & $\begin{array}{r}103 \\
493 \\
11\end{array}$ & $\begin{array}{r}90 \\
541 \\
10\end{array}$ & $\begin{array}{r}88 \\
496 \\
24\end{array}$ & $\begin{array}{r}77 \\
388 \\
10\end{array}$ & 20 & 3.46 \\
\hline $\begin{array}{l}\text { C.S.S. } \\
22 \mathrm{~F}\end{array}$ & $\begin{array}{l}\text { Glucose } \\
\text { NEFA } \\
\text { Insulin }\end{array}$ & $\begin{array}{r}58 \\
1,200 \\
7\end{array}$ & $\begin{array}{r}281 \\
912 \\
39\end{array}$ & $\begin{array}{r}172 \\
508 \\
31\end{array}$ & $\begin{array}{r}138 \\
508 \\
28\end{array}$ & $\begin{array}{r}124 \\
508 \\
27\end{array}$ & $\begin{array}{r}112 \\
559 \\
14\end{array}$ & $\begin{array}{r}99 \\
487 \\
24\end{array}$ & $\begin{array}{r}90 \\
519 \\
12\end{array}$ & $\begin{array}{r}84 \\
545 \\
7\end{array}$ & 20 & 3.46 \\
\hline${ }_{54}^{\mathrm{J}} . \mathrm{S}$. & $\begin{array}{l}\text { Glucose } \\
\text { NEFA } \\
\text { Insulin }\end{array}$ & $\begin{array}{r}86 \\
761 \\
19\end{array}$ & $\begin{array}{r}255 \\
761 \\
42\end{array}$ & $\begin{array}{r}198 \\
606 \\
54\end{array}$ & $\begin{array}{l}150 \\
511\end{array}$ & $\begin{array}{r}131 \\
542 \\
25\end{array}$ & $\begin{array}{l}116 \\
545\end{array}$ & $\begin{array}{r}91 \\
425 \\
23\end{array}$ & $\begin{array}{r}90 \\
425 \\
28\end{array}$ & $\begin{array}{r}63 \\
431 \\
23\end{array}$ & 26 & 2.67 \\
\hline $\begin{array}{l}\text { S.S. } \\
28 \mathrm{~F}\end{array}$ & $\begin{array}{l}\text { Glucose } \\
\text { NEFA } \\
\text { Insulin }\end{array}$ & $\begin{array}{r}90 \\
660 \\
18\end{array}$ & $\begin{array}{r}320 \\
892 \\
57\end{array}$ & $\begin{array}{r}232 \\
620 \\
42\end{array}$ & $\begin{array}{r}226 \\
475 \\
47\end{array}$ & $\begin{array}{r}194 \\
488 \\
46\end{array}$ & $\begin{array}{r}161 \\
454 \\
51\end{array}$ & $\begin{array}{r}142 \\
450 \\
53\end{array}$ & $\begin{array}{r}123 \\
423 \\
38\end{array}$ & $\begin{array}{r}104 \\
367 \\
15\end{array}$ & 36 & 1.92 \\
\hline $\begin{array}{l}\text { C.W. } \\
31 \mathrm{M}\end{array}$ & $\begin{array}{l}\text { Glucose } \\
\text { NEFA } \\
\text { Insulin }\end{array}$ & $\begin{array}{r}78 \\
1,266 \\
3\end{array}$ & $\begin{array}{r}242 \\
1,325 \\
38\end{array}$ & $\begin{array}{r}210 \\
1,053 \\
38\end{array}$ & $\begin{array}{r}155 \\
742 \\
40\end{array}$ & $\begin{array}{r}147 \\
681 \\
30\end{array}$ & $\begin{array}{r}121 \\
681 \\
20\end{array}$ & $\begin{array}{r}111 \\
548 \\
24\end{array}$ & $\begin{array}{r}103 \\
564 \\
40\end{array}$ & $\begin{array}{r}82 \\
564 \\
10\end{array}$ & 32 & 2.17 \\
\hline $\begin{array}{l}\text { Glucose } \\
\text { NEFA } \\
\text { Insulin }\end{array}$ & $\begin{array}{l}\text { Mean } \\
\text { SEM } \\
\text { Mean } \\
\text { SEM } \\
\text { Mean } \\
\text { SEM }\end{array}$ & $\begin{array}{r}78 \\
\pm 3 \\
772 \\
\pm 72 \\
11 \\
\pm 2\end{array}$ & $\begin{array}{r}248 \\
\pm 12 \\
797 \\
\pm 58 \\
45 \\
\pm 4\end{array}$ & $\begin{array}{r}181 \\
\pm 12 \\
616 \\
\pm 51 \\
36 \\
\pm 4\end{array}$ & $\begin{array}{r}145 \\
\pm 11 \\
528 \\
\pm 37 \\
28 \\
\pm 4\end{array}$ & $\begin{array}{r}123 \\
\pm 11 \\
475 \\
\pm 29 \\
27 \\
\pm 3\end{array}$ & $\begin{array}{r}109 \\
\pm 5 \\
499 \\
\pm 30 \\
18 \\
\pm 4\end{array}$ & $\begin{array}{r}93 \\
\pm 8 \\
459 \\
\pm 32 \\
22 \\
\pm 2\end{array}$ & $\begin{array}{r}89 \\
\pm 6 \\
493 \\
\pm 43 \\
20 \\
\pm 3\end{array}$ & $\begin{array}{r}77 \\
\pm 4 \\
477 \\
\pm 45 \\
16 \\
\pm 2\end{array}$ & $\begin{array}{r}25.3 \\
\pm 1.3\end{array}$ & $\begin{array}{r}2.74 \\
\pm 0.14\end{array}$ \\
\hline
\end{tabular}

* The units of measurement are: glucose, $\mathrm{mg}$ per $100 \mathrm{ml}$; nonesterified fatty acids (NEFA), $\mu \mathrm{Eq} / \mathrm{L} ;$ insulin, $\mu \mathrm{U} / \mathrm{ml}$. $\dagger \mathrm{K}_{\mathrm{c}}=$ glucose disappearance rate during control studies (per cent $\times$ minute ${ }^{-1}$ ).

$\ddagger \mathrm{K}_{\mathrm{e}}=$ glucose disappearance rate during fat meal-heparin studies (per cent $\times$ minute ${ }^{-1}$ ).

strated in the following manner: postheparin blood specimens from six subjects were each collected in two test tubes, one of which contained SAP-36,2 a polyanion in-

2 SAP-36 is a corn amylopectin kindly supplied by Dr. Peter Bernfeld, Bio-Research Institute, Cambridge, Mass. hibitor of lipoprotein lipase (29). When the rapid extraction technique was used, the average NEFA value was $1,007 \pm 125 \mu \mathrm{Eq}$ per $\mathrm{L}$ (standard error of the mean) for plasmas containing SAP-36, and 1,187 $\pm 191 \mu \mathrm{Eq}$ per $\mathrm{L}$ for plasmas without. This difference is statistically in- 
TABLE I

tests in normal subjects

\begin{tabular}{|c|c|c|c|c|c|c|c|c|c|c|c|c|c|}
\hline \multicolumn{14}{|c|}{ Fat meal-heparin } \\
\hline-180 & -15 & $\mathbf{0}$ & 8 & 16 & 24 & 32 & 40 & 48 & 56 & 64 & $t_{1}$ & $K_{\text {ef }}$ & $\frac{\mathrm{K}_{\mathrm{e}}}{\mathrm{K}_{\mathrm{c}}} \times 100$ \\
\hline $\begin{array}{r}94 \\
447 \\
18\end{array}$ & $\begin{array}{r}94 \\
690 \\
20\end{array}$ & $\begin{array}{r}98 \\
1,670 \\
18\end{array}$ & $\begin{array}{r}234 \\
1,604 \\
54\end{array}$ & $\begin{array}{r}231 \\
995 \\
40\end{array}$ & $\begin{array}{r}226 \\
958 \\
40\end{array}$ & $\begin{array}{r}191 \\
775 \\
42\end{array}$ & $\begin{array}{r}180 \\
742 \\
36\end{array}$ & $\begin{array}{r}155 \\
813 \\
33\end{array}$ & $\begin{array}{r}163 \\
597 \\
45\end{array}$ & $\begin{array}{r}141 \\
478 \\
44\end{array}$ & 81 & $\begin{array}{r}\text { minutes } \\
0.86\end{array}$ & 52 \\
\hline $\begin{array}{r}90 \\
565\end{array}$ & $\begin{array}{r}87 \\
717 \\
27\end{array}$ & $\begin{array}{r}99 \\
1,990 \\
18\end{array}$ & $\begin{array}{r}185 \\
1,737 \\
80\end{array}$ & $\begin{array}{r}124 \\
1,345 \\
45\end{array}$ & $\begin{array}{r}103 \\
1,086 \\
27\end{array}$ & $\begin{array}{r}89 \\
816 \\
22\end{array}$ & $\begin{array}{r}80 \\
839 \\
20\end{array}$ & $\begin{array}{r}75 \\
850 \\
21\end{array}$ & $\begin{array}{r}73 \\
837 \\
16\end{array}$ & $\begin{array}{r}75 \\
903 \\
14\end{array}$ & 21 & 3.30 & 52 \\
\hline $\begin{array}{r}83 \\
584 \\
9\end{array}$ & $\begin{array}{r}79 \\
1,030 \\
11\end{array}$ & $\begin{array}{r}76 \\
2,310 \\
8\end{array}$ & $\begin{array}{r}203 \\
1,804 \\
80\end{array}$ & $\begin{array}{r}151 \\
1,830 \\
64\end{array}$ & $\begin{array}{r}123 \\
1,278 \\
30\end{array}$ & $\begin{array}{r}106 \\
1,383 \\
32\end{array}$ & $\begin{array}{r}90 \\
1,614 \\
12\end{array}$ & $\begin{array}{r}80 \\
1,185 \\
19\end{array}$ & $\begin{array}{r}78 \\
1,250 \\
13\end{array}$ & $\begin{array}{r}77 \\
1,338 \\
8\end{array}$ & 27 & 2.57 & 45 \\
\hline $\begin{array}{r}79 \\
726 \\
9\end{array}$ & $\begin{array}{r}78 \\
1,205 \\
2\end{array}$ & $\begin{array}{r}80 \\
2,506 \\
2\end{array}$ & $\begin{array}{r}232 \\
1,471 \\
36\end{array}$ & $\begin{array}{r}197 \\
1,737 \\
40\end{array}$ & $\begin{array}{r}176 \\
962 \\
44\end{array}$ & $\begin{array}{r}155 \\
883 \\
24\end{array}$ & $\begin{array}{r}140 \\
510 \\
22\end{array}$ & $\begin{array}{r}127 \\
466 \\
12\end{array}$ & $\begin{array}{r}118 \\
633 \\
14\end{array}$ & $\begin{array}{r}107 \\
466 \\
6\end{array}$ & 49 & 1.41 & 45 \\
\hline $\begin{array}{r}98 \\
729 \\
13\end{array}$ & $\begin{array}{r}86 \\
869 \\
4\end{array}$ & $\begin{array}{r}86 \\
1,255 \\
6\end{array}$ & $\begin{array}{r}878 \\
85\end{array}$ & $\begin{array}{r}180 \\
769 \\
52\end{array}$ & $\begin{array}{r}139 \\
801 \\
36\end{array}$ & $\begin{array}{r}118 \\
801 \\
22\end{array}$ & $\begin{array}{r}97 \\
809 \\
20\end{array}$ & $\begin{array}{r}83 \\
862 \\
17\end{array}$ & $\begin{array}{r}85 \\
795 \\
6\end{array}$ & $\begin{array}{r}75 \\
729 \\
3\end{array}$ & 28 & 2.48 & 90 \\
\hline $\begin{array}{r}84 \\
563 \\
13\end{array}$ & $\begin{array}{r}70 \\
1,456 \\
8\end{array}$ & 21 & $\begin{array}{r}208 \\
2,412 \\
39\end{array}$ & $\begin{array}{r}127 \\
2,159 \\
18\end{array}$ & $\begin{array}{r}119 \\
1,538 \\
14\end{array}$ & $\begin{array}{r}110 \\
1,307 \\
11\end{array}$ & $\begin{array}{r}97 \\
1,062 \\
12\end{array}$ & $\begin{array}{r}90 \\
1,149 \\
16\end{array}$ & $\begin{array}{r}82 \\
922 \\
9\end{array}$ & $\begin{array}{r}78 \\
925 \\
13\end{array}$ & 41 & 1.69 & 78 \\
\hline $\begin{array}{r}94 \\
407 \\
9\end{array}$ & $\begin{array}{r}82 \\
638 \\
19\end{array}$ & $\begin{array}{r}92 \\
1,718 \\
18\end{array}$ & $\begin{array}{r}203 \\
1,386 \\
57\end{array}$ & $\begin{array}{r}179 \\
1,452 \\
42\end{array}$ & $\begin{array}{r}143 \\
1,229 \\
36\end{array}$ & $\begin{array}{r}123 \\
854 \\
32\end{array}$ & $\begin{array}{r}115 \\
854 \\
28\end{array}$ & $\begin{array}{r}82 \\
734 \\
26\end{array}$ & $\begin{array}{r}84 \\
734 \\
15\end{array}$ & $\begin{array}{r}90 \\
558 \\
15\end{array}$ & 37 & 1.87 & 70 \\
\hline $\begin{array}{r}71 \\
762 \\
4\end{array}$ & $\begin{array}{r}72 \\
872 \\
10\end{array}$ & $\begin{array}{r}73 \\
1,990 \\
6\end{array}$ & $\begin{array}{r}232 \\
1,428 \\
90\end{array}$ & $\begin{array}{r}173 \\
1,561 \\
38\end{array}$ & $\begin{array}{r}139 \\
999 \\
35\end{array}$ & $\begin{array}{r}118 \\
1,021 \\
28\end{array}$ & $\begin{array}{r}84 \\
753 \\
24\end{array}$ & $\begin{array}{r}76 \\
816 \\
25\end{array}$ & $\begin{array}{r}66 \\
755 \\
20\end{array}$ & $\begin{array}{l}66 \\
22\end{array}$ & 24 & 2.89 & 84 \\
\hline $\begin{array}{r}80 \\
992 \\
11\end{array}$ & $\begin{array}{r}71 \\
1,452 \\
8\end{array}$ & $\begin{array}{r}68 \\
1,931 \\
6\end{array}$ & $\begin{array}{r}290 \\
1,599 \\
91\end{array}$ & $\begin{array}{r}176 \\
1,122 \\
95\end{array}$ & $\begin{array}{r}128 \\
888 \\
53\end{array}$ & $\begin{array}{r}97 \\
904 \\
38\end{array}$ & $\begin{array}{r}89 \\
906 \\
18\end{array}$ & $\begin{array}{r}70 \\
763 \\
19\end{array}$ & $\begin{array}{r}66 \\
774 \\
17\end{array}$ & $\begin{array}{r}54 \\
774 \\
10\end{array}$ & 18 & 3.85 & 111 \\
\hline $\begin{array}{r}99 \\
403 \\
29\end{array}$ & $\begin{array}{r}89 \\
807 \\
19\end{array}$ & $\begin{array}{l}95 \\
22\end{array}$ & $\begin{array}{r}226 \\
1,630 \\
93\end{array}$ & $\begin{array}{r}210 \\
1,431 \\
70\end{array}$ & $\begin{array}{r}200 \\
1,165 \\
78\end{array}$ & $\begin{array}{r}164 \\
1,108 \\
65\end{array}$ & $\begin{array}{r}137 \\
835 \\
45\end{array}$ & $\begin{array}{r}145 \\
810 \\
47\end{array}$ & $\begin{array}{r}143 \\
681 \\
40\end{array}$ & $\begin{array}{r}120 \\
624 \\
28\end{array}$ & 57 & 1.18 & 44 \\
\hline $\begin{array}{r}93 \\
534 \\
29\end{array}$ & $\begin{array}{l}104 \\
810\end{array}$ & 10 & $\begin{array}{r}268 \\
2,140 \\
45\end{array}$ & $\begin{array}{r}262 \\
1,201 \\
35\end{array}$ & $\begin{array}{r}234 \\
747 \\
18\end{array}$ & $\begin{array}{r}171 \\
726 \\
63\end{array}$ & $\begin{array}{r}195 \\
603 \\
63\end{array}$ & $\begin{array}{r}186 \\
742 \\
70\end{array}$ & $\begin{array}{r}166 \\
857 \\
47\end{array}$ & $\begin{array}{r}150 \\
624 \\
55\end{array}$ & 68 & 1.02 & 53 \\
\hline $\begin{array}{r}89 \\
948 \\
15\end{array}$ & $\begin{array}{r}80 \\
1,067 \\
12\end{array}$ & $\begin{array}{r}78 \\
1,644 \\
2\end{array}$ & $\begin{array}{r}249 \\
1,444 \\
40\end{array}$ & $\begin{array}{r}188 \\
1,418 \\
34\end{array}$ & $\begin{array}{r}155 \\
1,161 \\
10\end{array}$ & $\begin{array}{r}121 \\
888 \\
15\end{array}$ & $\begin{array}{r}92 \\
775 \\
24\end{array}$ & $\begin{array}{r}77 \\
710 \\
22\end{array}$ & $\begin{array}{r}67 \\
532 \\
10\end{array}$ & $\begin{array}{r}64 \\
557 \\
9\end{array}$ & 23 & 3.02 & 139 \\
\hline $\begin{array}{r}88 \\
\pm 2 \\
589 \\
\pm 48 \\
14 \\
\pm 2\end{array}$ & $\begin{array}{r}83 \\
\pm 3 \\
926 \\
\pm 85 \\
13 \\
\pm 2\end{array}$ & $\begin{array}{r}79 \\
\pm 3 \\
1,840 \\
\pm 108 \\
11 \\
\pm 2\end{array}$ & $\begin{array}{r}230 \\
\pm 9 \\
1,628 \\
\pm 109 \\
66 \\
\pm 7\end{array}$ & $\begin{array}{r}183 \\
\pm 11 \\
1,418 \\
\pm 109 \\
47 \\
\pm 6\end{array}$ & $\begin{array}{r}157 \\
\pm 12 \\
1,068 \\
\pm 64 \\
35 \\
\pm 4\end{array}$ & $\begin{array}{r}130 \\
\pm 9 \\
956 \\
\pm 61 \\
33 \\
\pm 5\end{array}$ & $\begin{array}{r}116 \\
\pm 11 \\
859 \\
\pm 80 \\
27 \\
\pm 4\end{array}$ & $\begin{array}{r}104 \\
\pm 11 \\
825 \\
\pm 55 \\
27 \\
\pm 5\end{array}$ & $\begin{array}{r}99 \\
\pm 11 \\
781 \\
\pm 54 \\
22 \\
\pm 4\end{array}$ & $\begin{array}{r}91 \\
\pm 9 \\
725 \\
\pm 77 \\
19 \\
\pm 5\end{array}$ & $\begin{array}{r}39.5 \\
\pm 5.9\end{array}$ & $\begin{array}{r}1.75 \\
\pm 0.27\end{array}$ & \\
\hline
\end{tabular}

significant $(p>0.2)$ and demonstrates that very little in vitro lipolysis occurs during the rapid extraction procedure.

Insulin was assayed immunologically by a modification of the double antibody method of Morgan and Lazarow
(30). This modification consists of using a 72-hour incubation period for the initial antigen-antibody interaction and using a rabbit anti-guinea pig gamma-globulin serum for precipitating the insulin antibody complex. Human growth hormone was determined by the 

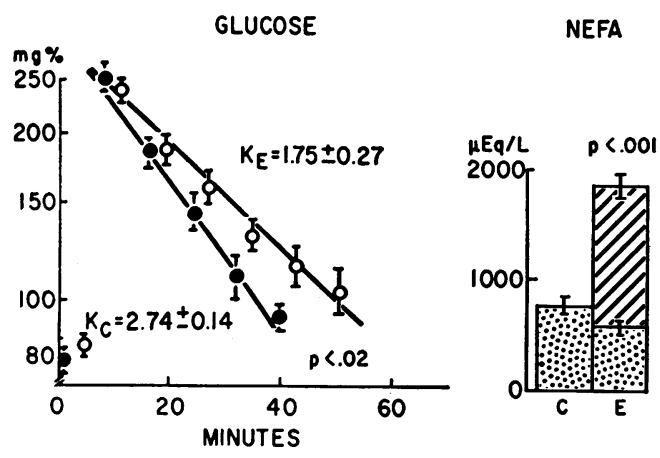

INSULIN

Fig. 3. EFfect of the fat MEAL-heparin Regimen on glucose disapPEARANCE, PLASMA NEFA, AND INSULIN SECRETION IN NORMAL SUBJECTS. 0 control study (C); $O=$ fat meal-heparin regimen (E); I = SEM. Rate constants $(\mathrm{K})$ are expressed as per cent $\times$ minutes $^{-1} \pm \mathrm{SEM}$. The fasting plasma NEFA levels are represented by stippled bars, and the elevation after the fat meal-heparin regimen by the cross-hatched bar above.

radioimmunoassay method of Schalch and Parker (31). Plasmas assayed for insulin and human growth hormone were stored at $-20^{\circ} \mathrm{C}$ until used. Since pancreatic insulin secretion could not be measured directly in these studies, the area circumscribed by the plasma insulin response curve has been used as an index of insulin secretion and is expressed as microunit-minutes per milliliter.

\section{Results}

Effect of the fat meal-heparin regimen on plasma levels of NEFA, glucose, insulin, and growth hormone. Three normal subjects were studied on two or more occasions after an overnight fast to determine the effect of the fat mealheparin regimen on plasma NEFA, glucose, insulin, and growth hormone (Figure 1). Three hours after the ingestion of the fat meal, the plasma

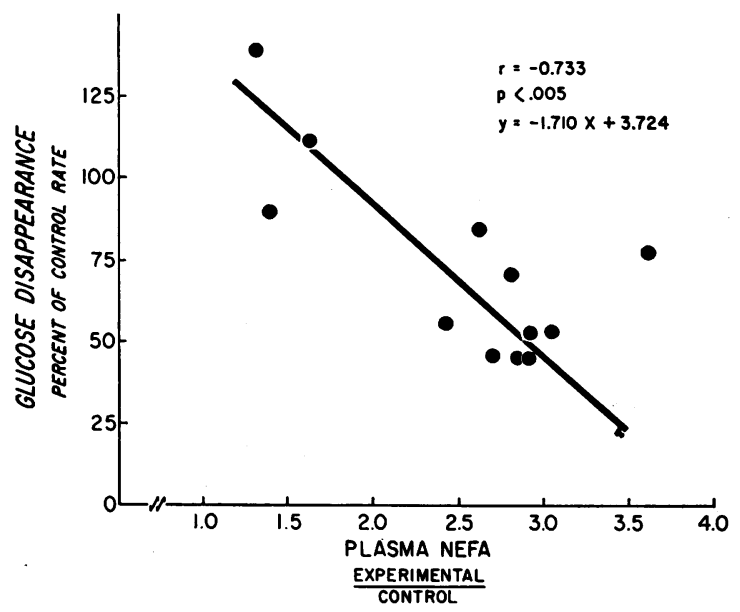

Fig. 4. Change in Rate of glucose disappearance in RELATION TO THE INCREASE IN PLASMA NEFA.
NEFA content rose from an average fasting level of $488 \pm 45 \mu \mathrm{Eq}$ per $\mathrm{L}$ to $767 \pm 11 \mu \mathrm{Eq}$ per $\mathrm{L}$. After the intravenous injection of $50 \mathrm{mg}$ of heparin sodium, the plasma NEFA level increased rapidly to $1,929 \pm 274 \mu \mathrm{Eq}$ per $\mathrm{L}$ and remained greater than $1,300 \mu \mathrm{Eq}$ per $\mathrm{L}$ for over an hour. Throughout this period, the plasma levels of glucose and insulin remained unchanged, and the level of growth hormone remained less than $1 \mathrm{~m} \mu \mathrm{g}$ per $\mathrm{ml}$.

Effect of either a fat meal or intravenous heparin on carbohydrate tolerance. The glucose disappearance rate did not change significantly from control values when measured in three normal subjects on two or more occasions either 3 hours after the ingestion of a fat meal alone or $15 \mathrm{~min}$ utes after the intravenous administration of 50 $\mathrm{mg}$ heparin sodium (Figure 2). In these individuals, the plasma NEFA level increased from an average fasting level of $502 \pm 73 \mu \mathrm{Eq}$ per $\mathrm{L}$ to $674 \pm 177 \mu \mathrm{Eq}$ per L after the fat meal. After intravenous heparin alone the increase in plasma NEFA was from $597 \pm 79 \mu \mathrm{Eq}$ per $\mathrm{L}$ to $970 \pm$ $167 \mu \mathrm{Eq}$ per $\mathrm{L}$, but the rise was transient with a return to normal fasting levels within 10 to 15 minutes. Plasma insulin response during these studies did not differ significantly from that seen under control conditions (control 1,617 \pm 112 , fat meal $1,168 \pm 154$, heparin $1,147 \pm 152 \mu \mathrm{U}$-minutes per $\mathrm{ml}$.

Effect of fat meal-heparin regimen on carbohydrate tolerance in normal subjects. The carbohydrate tolerance in twelve normal subjects was 
studied under both control conditions and after the administration of a fat meal and heparin regimen (Table I). The fat meal-heparin regimen resulted in a marked reduction $(>45 \%)$ in carbohydrate tolerance in six subjects, a moderate reduction $(>16 \%)$ in three others, and no reduction in the remaining three subjects (G.L., C.S., C.W.). When compared to the mean control $\mathrm{K}$ value, the average decrease in the glucose disappearance rate after the fat meal-heparin regimen was $36.1 \%$, dropping from a mean base-line value of $2.74 \pm 0.14$ to a mean experimental value of $1.75 \pm 0.27 \%$ per minute (Figure 3 ). This decrease is significant with a $\mathrm{p}$ value $<0.02$. All three subjects that showed no reduction (two actually showed an increase) in the glucose disappearance rate during the fat meal-heparin study had markedly elevated fasting plasma NEFA levels on the day of the control study $(915,1,200,1,266$ $\mu \mathrm{Eq}$ per $\mathrm{L}$ ). The average fasting plasma NEFA level during the control studies for the twelve normal subjects was $772 \pm 72 \mu \mathrm{Eq}$ per L. During the experimental studies the average fasting plasma NEFA level of $589 \pm 48 \mu \mathrm{Eq}$ per L showed a significant rise to $1,840 \pm 108 \mu \mathrm{Eq}$ per $\mathrm{L}(\mathrm{p}<0.005)$ after the administration of a fat meal and intravenous heparin. The average insulin secretion (as previously defined) in response to $25 \mathrm{~g}$ of iv glucose was $1,878 \pm 159 \mu \mathrm{U}$-minutes per ml during the control studies, and increased significantly $(\mathrm{p}<0.05)$ to $2,352 \pm 231 \mu \mathrm{U}$-minutes per $\mathrm{ml}$ during the fat meal-heparin studies.

The degree of impairment of glucose tolerance in these normal subjects closely paralleled the increase in plasma NEFA level. The regression line, plotted by the method of least squares, relating the glucose utilization rate seen after the fat meal-heparin regimen and the corresponding increase in plasma NEFA level is recorded in Figure 4. The coefficient of correlation ( $r$ ) equals -0.733 and is significant with a $p$ value of $<0.005$.

Effect of fat meal-heparin regimen on carbohydrate tolerance in mild diabetes mellitus. Similar studies were performed on five mild diabetics who were controlled on diet alone and had normal fasting blood sugar and plasma NEFA levels (Table II). During the control studies, the average glucose disappearance rate of the diabetic group was $1.24 \pm 0.16 \%$ per minute (Figure 5), approxi- mately $45 \%$ of the control value for normal subjects. After the fat meal-heparin regimen, the mean plasma NEFA level rose from the fasting value of $578 \pm 84 \mu \mathrm{Eq}$ per $\mathrm{L}$ to $2,101 \pm 471 \mu \mathrm{Eq}$ per $L$, but there was no further impairment in carbohydrate tolerance $(\mathrm{K}=1.24 \pm 0.18)$. It should be noted that the reduced glucose disappearance rate in normal individuals on the fatheparin regimen $(K=1.75 \pm 0.27)$ approaches the disappearance rate in these diabetic subjects. The plasma insulin response in diabetic patients during the control study was $1,861 \pm 417 \mu U$-minutes per ml, only slightly less than that seen in normal individuals, and it was not significantly altered during the fat meal-heparin period $(2,318 \pm$ $167 \mu \mathrm{U}$-minutes per $\mathrm{ml}$ ).

Temporal relationship between the fatty acid mobilizing activity and the insulin antagonistic effect of growth hormone. Since these studies indicate that an increase in the level of circulating NEFA may be associated with impaired carbohydrate tolerance and insulin responsiveness, the temporal relationship between the fatty acid mobilizing activity of human growth hormone (HGH) and its well-known insulin antagonistic action was explored. After initial base-line studies, repeat intravenous glucose tolerance tests were performed on seven normal subjects on different days at 10,60 , and 120 minutes after the intravenous administration of $5 \mathrm{mg}$ of human growth hormone (Table III). Ten minutes after the administration of growth hormone (Figure 6), its acute "insulin-like effect" produced an average increase of $32 \%$ in the glucose disappearance rate over the mean control value for the same subjects $(\mathrm{p}<0.005)$. Sixty minutes after $\mathrm{HGH}$ administration, the average glucose disappearance rate returned to approximately the control value. The average plasma NEFA levels 10 and 60 minutes after $\mathrm{HGH}$ administration were insignificantly different from the mean control value. One hundred twenty minutes after the administration of $\mathrm{HGH}$, the glucose disappearance rate decreased $48 \%$ from the control value $(p<0.005)$ while at the same time the plasma NEFA level rose $103 \%$ over the mean fasting value $(p<0.005)$.

\section{Discussion}

The results of this study support the proposal of Randle and his associates (18) that the circu- 
TABLE II

Intravenous glucose tolerance

\begin{tabular}{|c|c|c|c|c|c|c|c|c|c|c|c|c|}
\hline \multirow{2}{*}{$\begin{array}{l}\text { Subject } \\
\text { Age, Sex }\end{array}$} & \multirow[b]{2}{*}{ Minutes } & \multicolumn{11}{|c|}{ Control } \\
\hline & & $\mathbf{0}$ & 8 & 16 & 24 & 32 & 40 & 48 & 56 & 64 & $t_{1}$ & $\mathrm{~K}_{\mathrm{o}}$ \\
\hline $\begin{array}{l}\text { F.B. } \\
51 \text {. }\end{array}$ & $\begin{array}{l}\text { Glucose* } \\
\text { NEFA } \\
\text { Insulin }\end{array}$ & $\begin{array}{r}88 \\
572 \\
7\end{array}$ & $\begin{array}{r}254 \\
614 \\
19\end{array}$ & $\begin{array}{r}220 \\
593 \\
15\end{array}$ & $\begin{array}{r}195 \\
489 \\
10\end{array}$ & $\begin{array}{r}167 \\
534 \\
18\end{array}$ & $\begin{array}{r}165 \\
500 \\
10\end{array}$ & $\begin{array}{r}150 \\
468 \\
6\end{array}$ & $\begin{array}{r}137 \\
521 \\
15\end{array}$ & $\begin{array}{r}116 \\
383 \\
14\end{array}$ & $\begin{array}{c}\text { minutes } \\
52\end{array}$ & 1.33 \\
\hline $\begin{array}{l}\text { M.G. } \\
50 \mathrm{~F}\end{array}$ & $\begin{array}{l}\text { Glucose } \\
\text { NEFA } \\
\text { Insulin }\end{array}$ & $\begin{array}{r}77 \\
510 \\
4\end{array}$ & $\begin{array}{r}265 \\
696 \\
8\end{array}$ & $\begin{array}{r}237 \\
498 \\
9\end{array}$ & $\begin{array}{r}238 \\
673 \\
14\end{array}$ & $\begin{array}{r}217 \\
408 \\
30\end{array}$ & $\begin{array}{r}202 \\
304 \\
30\end{array}$ & $\begin{array}{r}173 \\
330 \\
22\end{array}$ & $\begin{array}{r}182 \\
438 \\
10\end{array}$ & $\begin{array}{r}174 \\
338 \\
12\end{array}$ & 83 & 0.84 \\
\hline $\begin{array}{l}\text { L.H. } \\
20 \mathrm{~F}\end{array}$ & $\begin{array}{l}\text { Glucose } \\
\text { NEFA } \\
\text { Insulin }\end{array}$ & $\begin{array}{r}75 \\
450 \\
13\end{array}$ & $\begin{array}{r}234 \\
412 \\
53\end{array}$ & $\begin{array}{r}194 \\
490 \\
42\end{array}$ & $\begin{array}{r}171 \\
344 \\
38\end{array}$ & $\begin{array}{r}148 \\
490 \\
40\end{array}$ & $\begin{array}{r}137 \\
440 \\
34\end{array}$ & $\begin{array}{r}114 \\
402 \\
16\end{array}$ & $\begin{array}{r}106 \\
4.59 \\
33\end{array}$ & $\begin{array}{r}98 \\
419 \\
37\end{array}$ & 40 & 1.73 \\
\hline $\begin{array}{l}\text { W.J. } \\
56 \mathrm{~F}\end{array}$ & $\begin{array}{l}\text { Glucose } \\
\text { NEFA } \\
\text { Insulin }\end{array}$ & $\begin{array}{r}96 \\
707 \\
25\end{array}$ & $\begin{array}{r}308 \\
846 \\
36\end{array}$ & $\begin{array}{r}266 \\
691 \\
44\end{array}$ & $\begin{array}{r}214 \\
657 \\
52\end{array}$ & $\begin{array}{r}208 \\
538 \\
40\end{array}$ & $\begin{array}{r}194 \\
657 \\
48\end{array}$ & $\begin{array}{r}176 \\
451 \\
48\end{array}$ & $\begin{array}{r}158 \\
728 \\
46\end{array}$ & $\begin{array}{r}144 \\
799 \\
46\end{array}$ & 48 & 1.44 \\
\hline $\begin{array}{l}\text { B.W. } \\
23 \mathrm{M}\end{array}$ & $\begin{array}{l}\text { Glucose } \\
\text { NEFA } \\
\text { Insulin }\end{array}$ & $\begin{array}{r}94 \\
532 \\
16\end{array}$ & $\begin{array}{r}226 \\
614 \\
41\end{array}$ & $\begin{array}{r}188 \\
561 \\
26\end{array}$ & $\begin{array}{r}173 \\
534 \\
30\end{array}$ & $\begin{array}{r}167 \\
588 \\
32\end{array}$ & $\begin{array}{r}155 \\
540 \\
29\end{array}$ & $\begin{array}{r}150 \\
866 \\
26\end{array}$ & $\begin{array}{r}132 \\
417 \\
30\end{array}$ & $\begin{array}{r}118 \\
372 \\
16\end{array}$ & 59 & 1.18 \\
\hline $\begin{array}{l}\text { Glucose } \\
\text { NEFA } \\
\text { Insulin }\end{array}$ & $\begin{array}{l}\text { Mean } \\
\text { SEM } \\
\text { Mean } \\
\text { SEM } \\
\text { Mean } \\
\text { SEM }\end{array}$ & $\begin{array}{r}86 \\
\pm 5 \\
554 \\
\pm 43 \\
13 \\
\pm 4\end{array}$ & $\begin{array}{r}257 \\
\pm 14 \\
636 \\
\pm 70 \\
31 \\
\pm 8\end{array}$ & $\begin{array}{r}221 \\
\pm 14 \\
567 \\
\pm 36 \\
37 \\
\pm 7\end{array}$ & $\begin{array}{r}198 \\
\pm 13 \\
539 \\
\pm 60 \\
29 \\
\pm 8\end{array}$ & $\begin{array}{r}181 \\
\pm 13 \\
512 \\
\pm 30 \\
32 \\
\pm 4\end{array}$ & $\begin{array}{r}171 \\
\pm 12 \\
488 \\
\pm 58 \\
28 \\
\pm 6\end{array}$ & $\begin{array}{r}153 \\
\pm 11 \\
503 \\
\pm 94 \\
24 \\
\pm 7\end{array}$ & $\begin{array}{r}143 \\
\pm 13 \\
513 \\
\pm 57 \\
27 \\
\pm 6\end{array}$ & $\begin{array}{r}130 \\
\pm 13 \\
462 \\
\pm 85 \\
23 \\
\pm 5\end{array}$ & $\begin{array}{r}56 \\
+7\end{array}$ & $\begin{array}{r}1.24 \\
\pm 0.17\end{array}$ \\
\hline
\end{tabular}

* The units of measurement are: glucose, $\mathrm{mg}$ per $100 \mathrm{ml}$; NEFA, $\mu \mathrm{Eq}$ per L; insulin, $\mu \mathrm{U}$ per ml.

lating level of nonesterified fatty acids may be an important factor in regulating the glucose tolerance and insulin responsiveness of the intact organism. The rapid intravenous glucose tolerance test, used in this study for assessing glucose disappearance rates in the total organism, does not per- mit conclusions regarding the changes induced by the fat meal-heparin regimen on the metabolism of glucose by specific organ systems, in particular, striated muscle, adipose tissue, and liver. On the basis of in vitro studies, however, increased NEFA concentrations would be expected to decrease the
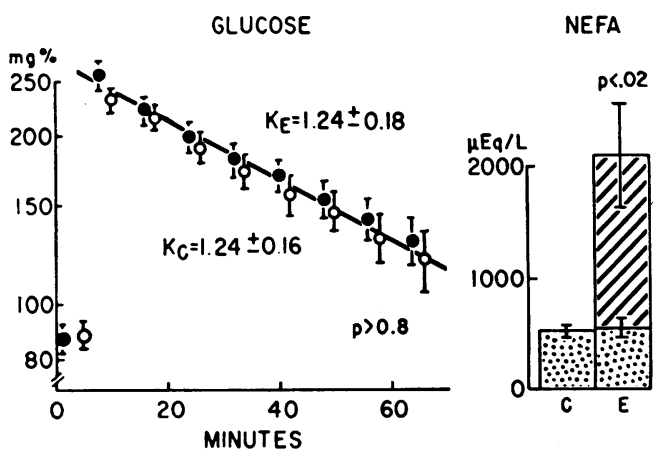

INSULIN

Fig. 5. EFFect of the fat MEAL-HEPARIN REgIMEN ON GLUCOSE DisapPEARANCE, PLASMA NEFA, AND INSULIN SECRETION IN SUBJECTS WITH MILD DIABETES MELLITUS. $O=$ control study (C); $O=$ fat meal-heparin regimen (E) ; I = SEM. Rate constants (K) are expressed as per cent $\times$ minutes $^{-1}$ \pm SEM. The fasting plasma NEFA levels are represented by stippled bars, and the elevatioin after the fat meal-heparin regimen by the cross-hatched bar above. 
TABLE II

tests in diabetic subjects

\begin{tabular}{|c|c|c|c|c|c|c|c|c|c|c|c|c|c|}
\hline \multicolumn{14}{|c|}{ Fat meal-heparin } \\
\hline-180 & -15 & 0 & 8 & 16 & 24 & 32 & 40 & 48 & 56 & 64 & $t_{3}$ & $\mathrm{~K}_{\mathrm{e}}$ & $\frac{\mathrm{K}_{\mathrm{o}}}{\mathrm{K}_{\mathrm{c}}} \times 100$ \\
\hline & & & & & & & & & & & minutes & & \\
\hline $\begin{array}{r}100 \\
798 \\
21\end{array}$ & $\begin{array}{r}83 \\
1,072 \\
12\end{array}$ & $\begin{array}{r}95 \\
2,456 \\
13\end{array}$ & $\begin{array}{r}208 \\
2,317 \\
40\end{array}$ & $\begin{array}{r}194 \\
2,783 \\
29\end{array}$ & $\begin{array}{r}168 \\
2,104 \\
34\end{array}$ & $\begin{array}{r}145 \\
1,966 \\
35\end{array}$ & $\begin{array}{r}129 \\
1,186 \\
28\end{array}$ & $\begin{array}{r}136 \\
30\end{array}$ & $\begin{array}{r}117 \\
1,431 \\
25\end{array}$ & $\begin{array}{r}105 \\
1,540 \\
24\end{array}$ & 56 & 1.24 & 93 \\
\hline $\begin{array}{r}78 \\
761 \\
15\end{array}$ & $\begin{array}{r}90 \\
2,091 \\
18\end{array}$ & $\begin{array}{r}100 \\
3,727 \\
19\end{array}$ & $\begin{array}{r}249 \\
2,383 \\
39\end{array}$ & $\begin{array}{r}246 \\
1,559 \\
33\end{array}$ & $\begin{array}{r}222 \\
1,681 \\
23\end{array}$ & $\begin{array}{r}207 \\
1,293 \\
26\end{array}$ & $\begin{array}{r}196 \\
1,399 \\
25\end{array}$ & $\begin{array}{r}180 \\
832 \\
43\end{array}$ & $\begin{array}{r}168 \\
939 \\
34\end{array}$ & $\begin{array}{r}154 \\
755 \\
48\end{array}$ & 78 & 0.89 & 106 \\
\hline $\begin{array}{r}84 \\
397 \\
18\end{array}$ & $\begin{array}{r}61 \\
798 \\
24\end{array}$ & $\begin{array}{r}88 \\
1,930 \\
7\end{array}$ & $\begin{array}{r}243 \\
2,170 \\
64\end{array}$ & $\begin{array}{r}218 \\
1,777 \\
33\end{array}$ & $\begin{array}{r}193 \\
1,578 \\
38\end{array}$ & $\begin{array}{r}178 \\
1,372 \\
35\end{array}$ & $\begin{array}{r}166 \\
1,219 \\
33\end{array}$ & $\begin{array}{r}156 \\
1,095 \\
34\end{array}$ & $\begin{array}{r}147 \\
1,000 \\
34\end{array}$ & $\begin{array}{r}136 \\
842 \\
30\end{array}$ & 57 & 1.22 & 71 \\
\hline $\begin{array}{r}122 \\
443 \\
20\end{array}$ & $\begin{array}{r}78 \\
578 \\
23\end{array}$ & $\begin{array}{r}75 \\
1,205 \\
8\end{array}$ & $\begin{array}{r}253 \\
938 \\
26\end{array}$ & $\begin{array}{r}227 \\
853 \\
35\end{array}$ & $\begin{array}{r}210 \\
716 \\
48\end{array}$ & $\begin{array}{r}192 \\
532 \\
58\end{array}$ & $\begin{array}{r}180 \\
841 \\
46\end{array}$ & $\begin{array}{r}158 \\
596 \\
28\end{array}$ & $\begin{array}{r}141 \\
705 \\
30\end{array}$ & $\begin{array}{r}130 \\
759 \\
25\end{array}$ & 59 & 1.17 & 81 \\
\hline $\begin{array}{r}84 \\
489 \\
22\end{array}$ & $\begin{array}{r}558 \\
25\end{array}$ & $\begin{array}{r}82 \\
1,189 \\
11\end{array}$ & $\begin{array}{r}199 \\
1,053 \\
60\end{array}$ & $\begin{array}{r}190 \\
979 \\
34\end{array}$ & $\begin{array}{r}159 \\
816 \\
41\end{array}$ & $\begin{array}{r}138 \\
851 \\
30\end{array}$ & $\begin{array}{r}121 \\
670 \\
30\end{array}$ & $\begin{array}{r}107 \\
681 \\
28\end{array}$ & $\begin{array}{r}88 \\
747 \\
15\end{array}$ & $\begin{array}{r}74 \\
854 \\
22\end{array}$ & 40 & 1.73 & 147 \\
\hline $\begin{array}{r}94 \\
\pm 8 \\
578 \\
\pm 84 \\
19 \\
\pm 1\end{array}$ & $\begin{array}{r}78 \\
\pm 6 \\
1,019 \\
\pm 284 \\
20 \\
\pm 2\end{array}$ & $\begin{array}{r}88 \\
\pm 5 \\
2,101 \\
\pm 471 \\
12 \\
\pm 2\end{array}$ & $\begin{array}{r}230 \\
\pm 12 \\
1,772 \\
\pm 319 \\
46 \\
\pm 6\end{array}$ & $\begin{array}{r}215 \\
\pm 10 \\
1,590 \\
\pm 266 \\
33 \\
\pm 2\end{array}$ & $\begin{array}{r}190 \\
\pm 12 \\
1,379 \\
\pm 266 \\
37 \\
\pm 4\end{array}$ & $\begin{array}{r}172 \\
\pm 13 \\
1,203 \\
\pm 244 \\
37 \\
\pm 6\end{array}$ & $\begin{array}{r}158 \\
\pm 14 \\
1,023 \\
\pm 113 \\
32 \\
\pm 4\end{array}$ & $\begin{array}{r}147 \\
\pm 12 \\
801 \\
\pm 109 \\
33 \\
\pm 3\end{array}$ & $\begin{array}{r}132 \\
\pm 14 \\
964 \\
\pm 129 \\
28 \\
\pm 4\end{array}$ & $\begin{array}{r}120 \\
\pm 16 \\
950 \\
\pm 149 \\
30 \\
\pm 5\end{array}$ & $\begin{array}{r}58 \\
\pm 6\end{array}$ & $\begin{array}{r}1.24 \\
\pm 0.18\end{array}$ & $\begin{array}{r}100 \\
\pm 13\end{array}$ \\
\hline
\end{tabular}

rate of glucose utilization by striated muscle and impair the sensitivity of this tissue to insulin (1922). Adipose tissue, on the other hand, might conceivably respond in a different manner. Leboeuf and Cahill (32) have reported that increased levels of nonesterified fatty acids stimulate glucose uptake, glucose oxidation to $\mathrm{CO}_{2}$, and glucose conversion to glyceride-glycerol by the rat epididymal fat pad preparation in vitro. The similar effects of fatty acids, epinephrine, ACTH, and growth hormone on glucose metabolism of adipose tissue have led these investigators to suggest that the hormone-induced changes in glucose utilization in this tissue are secondary to their lipolytic activity. Although every precaution was taken to perform the control and fat meal-heparin studies under as comparable conditions as possible, it is readily acknowledged that individual differences in the rate of release of endogenous epinephrine during these studies may have produced some of the variability observed in the glucose disappearance rates in the normal subjects during periods of normal and elevated plasma NEFA levels. The effect of fatty acids on hepatic glucose metabolism has not been systematically studied, but it has been reported that the intravenous infusion of sodium octanoate at a rate sufficient to produce a significant ketonemia did not affect net splanchnic glucose production (33).

The temporal correlation between the appearance of increased plasma NEFA levels and decreased glucose disappearance rates that follow the intravenous injection of human growth hormone is consistent with the concept that the insulin antagonistic effect of growth hormone is secondary to its lipolytic activity. The severity of impairment of glucose tolerance after growth hormone administration, however, is greater than would have been predicted from the plasma NEFA level, using as a basis of comparison the relationship between acute elevation in plasma NEFA level and the associated decrease in glucose disappearance rate seen after the fat meal-heparin regimen (Figure 4). This apparent discrepancy could be accounted for if the intracellular rather than the extracellular concentration of free fatty acids is the significant factor influencing glucose metabolism. In this context, raising the extracellular free fatty 
TABLE III

Intravenous glucose tolerance tests in normal subjects

\begin{tabular}{|c|c|c|c|c|c|c|c|c|c|c|c|c|}
\hline \multirow[b]{2}{*}{ Subject } & \multirow[b]{2}{*}{ Minutes: } & \multirow{2}{*}{$\underset{0^{*}}{\text { NEFA }}$} & \multicolumn{10}{|c|}{$\begin{array}{l}\text { Control } \\
\text { Glucose }\end{array}$} \\
\hline & & & $0^{*}$ & 5 & 10 & 15 & 20 & 25 & 30 & 40 & $t_{\frac{1}{2}}$ & $\mathrm{~K} \dagger$ \\
\hline & \multicolumn{3}{|c|}{$\mu E q / L$} & \multicolumn{6}{|c|}{$m g$ per $100 \mathrm{ml}$} & \multicolumn{3}{|c|}{ minutes } \\
\hline $\begin{array}{l}\text { G.C. } \\
\text { H.D. } \\
\text { J.F. } \\
\text { D.H. } \\
\text { E.M. } \\
\text { J.S. } \\
\text { D.T. }\end{array}$ & & $\begin{array}{l}553 \\
614 \\
537 \\
479 \\
844 \\
596 \\
660\end{array}$ & $\begin{array}{r}91 \\
93 \\
72 \\
108 \\
76 \\
86 \\
86\end{array}$ & $\begin{array}{l}242 \\
248 \\
262 \\
267 \\
297 \\
255 \\
246\end{array}$ & $\begin{array}{l}236 \\
217 \\
222 \\
190 \\
260 \\
198 \\
212\end{array}$ & $\begin{array}{l}214 \\
203 \\
184 \\
117 \\
191 \\
196\end{array}$ & $\begin{array}{l}201 \\
183 \\
152 \\
128 \\
157 \\
150 \\
178\end{array}$ & $\begin{array}{l}178 \\
171 \\
132 \\
105 \\
138 \\
131 \\
174\end{array}$ & $\begin{array}{r}153 \\
165 \\
98 \\
81 \\
124 \\
116 \\
158\end{array}$ & $\begin{array}{r}132 \\
136 \\
78 \\
\\
100 \\
91 \\
128\end{array}$ & $\begin{array}{l}45 \\
49 \\
20 \\
20 \\
20 \\
26 \\
42\end{array}$ & $\begin{array}{l}1.54 \\
1.41 \\
3.46 \\
3.46 \\
3.46 \\
2.67 \\
1.65\end{array}$ \\
\hline \multirow[t]{2}{*}{$\begin{array}{l}\text { Mean } \\
\text { SEM }\end{array}$} & & $\begin{array}{c}612 \\
\pm 44.5\end{array}$ & $\begin{array}{r}87.4 \\
\pm 4.5\end{array}$ & $\begin{array}{l}260 \\
\pm 7.1\end{array}$ & $\begin{array}{l}219 \\
\pm 8.9\end{array}$ & $\begin{array}{c}184 \\
\pm 14.1\end{array}$ & $\begin{array}{l}164 \\
\pm 9.3\end{array}$ & $\begin{array}{c}147 \\
\pm 11.9\end{array}$ & $\begin{array}{c}128 \\
\pm 12.1\end{array}$ & $\begin{array}{r}111 \\
\pm 10\end{array}$ & $\begin{array}{r}31.7 \\
\pm 4.9\end{array}$ & $\begin{array}{r}2.19 \\
\pm 0.35\end{array}$ \\
\hline & & & \multicolumn{10}{|c|}{60 Minutes After HGH } \\
\hline $\begin{array}{l}\text { G.C. } \\
\text { H.D. } \\
\text { J.F. } \\
\text { D.H. } \\
\text { J.S. } \\
\text { D.T. }\end{array}$ & & $\begin{array}{l}449 \\
516 \\
612 \\
680 \\
548 \\
259\end{array}$ & $\begin{array}{r}86 \\
83 \\
91 \\
97 \\
106 \\
87\end{array}$ & $\begin{array}{l}237 \\
227 \\
247 \\
255 \\
284 \\
223\end{array}$ & $\begin{array}{l}226 \\
197 \\
204 \\
200 \\
217 \\
195\end{array}$ & $\begin{array}{l}214 \\
183 \\
188 \\
172 \\
196 \\
167\end{array}$ & $\begin{array}{l}196 \\
177 \\
170 \\
144 \\
169 \\
144\end{array}$ & $\begin{array}{l}190 \\
173 \\
155 \\
140 \\
160 \\
140\end{array}$ & $\begin{array}{l}162 \\
163 \\
130 \\
116 \\
145 \\
128\end{array}$ & $\begin{array}{r}138 \\
153 \\
103 \\
92 \\
102 \\
120\end{array}$ & $\begin{array}{l}44 \\
68 \\
27 \\
23 \\
29 \\
32\end{array}$ & $\begin{array}{l}1.58 \\
1.02 \\
2.57 \\
3.01 \\
2.39 \\
2.16\end{array}$ \\
\hline $\begin{array}{l}\text { Mean } \\
\text { SEM }\end{array}$ & & $\begin{array}{c}511 \\
\pm 59.9\end{array}$ & $\begin{array}{r}97.7 \\
\pm 3.5\end{array}$ & $\begin{array}{l}246 \\
\pm 9.1\end{array}$ & $\begin{array}{l}216 \\
\pm 5.0\end{array}$ & $\begin{array}{l}187 \\
\pm 6.9\end{array}$ & $\begin{array}{l}167 \\
\pm 8.2\end{array}$ & $\begin{array}{l}160 \\
\pm 7.9\end{array}$ & $\begin{array}{l}141 \\
\pm 7.9\end{array}$ & $\begin{array}{l}118 \\
\pm 9.6\end{array}$ & $\begin{array}{r}37.2 \\
\pm 6.8\end{array}$ & $\begin{array}{r}1.86 \\
\pm 0.35\end{array}$ \\
\hline
\end{tabular}

* Zero minutes denotes the time immediately before the intravenous administration of $25 \mathrm{~g}$ of glucose.

$\dagger \mathrm{K}=$ glucose disappearance rate (per cent $\times$ minute $^{-1}$ ).

$\ddagger \mathrm{HGH}=$ human growth hormone.

acid level, e.g., a fat meal-heparin regimen, appears to be less effective in increasing the intracellular fatty acid content than hormone-stimulated lipolysis. Consistent with this suggestion are the results of Verner, Blackard, and Engel (34), who demonstrated that epinephrine-induced lipolysis was not associated with increased glucose uptake in adipose tissue if the intracellular free fatty acid content was permitted to rise. Increased glucose utilization did occur, however, if a fatty acid ac-

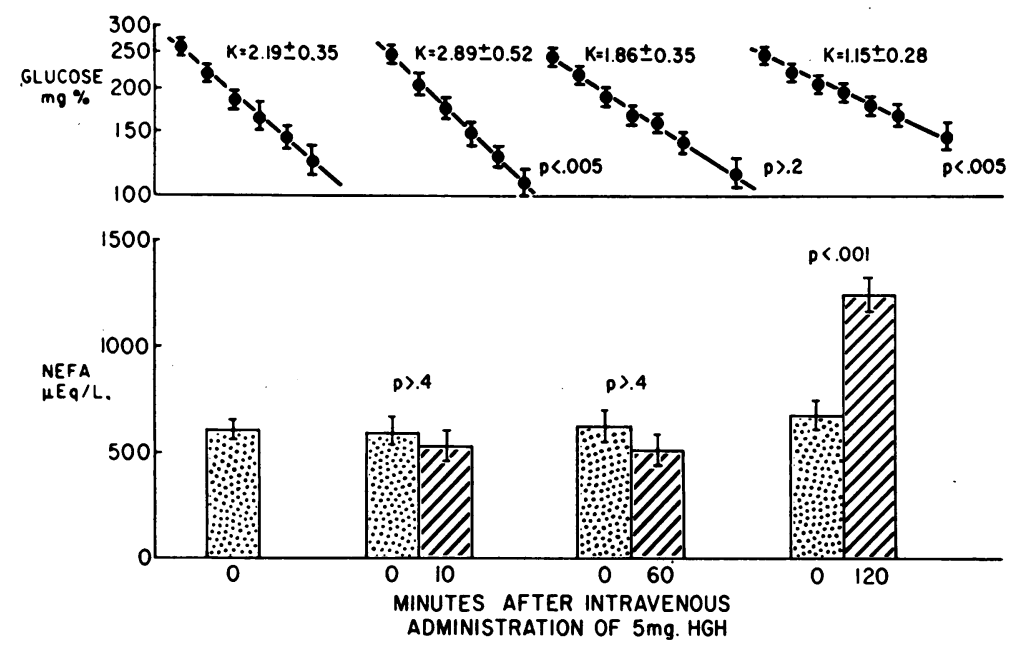

Fig. 6. EFFECt OF the intravenous administration of human growth HORMONE ON GLUCOSE DISAPPEARANCE AND PLASMA NEFA. Average plasma NEFA values immediately before the administration of $5 \mathrm{mg}$ human growth hormone $(\mathrm{HGH})$ are represented by the stippled bars and before the intravenous administration of $25 \mathrm{~g}$ of glucose by the cross-hatched bars below each corresponding glucose disappearance curve. 
TABLE III

after 5 mg of intravenous human growth hormone

\begin{tabular}{|c|c|c|c|c|c|c|c|c|c|c|}
\hline \multirow{2}{*}{$\underset{0^{*}}{\text { NEFA }}$} & \multicolumn{10}{|c|}{$\begin{array}{c}\text { Minutes After HGH } \\
\text { Glucose }\end{array}$} \\
\hline & $0 *$ & 5 & 10 & 15 & 20 & 25 & 30 & 40 & $t_{1}$ & $\mathbf{K}$ \\
\hline$\mu E q / L$ & \multicolumn{7}{|c|}{$m g$ per $100 \mathrm{ml}$} & \multicolumn{3}{|c|}{ minutes } \\
\hline $\begin{array}{l}736 \\
412 \\
277 \\
530 \\
667\end{array}$ & $\begin{array}{r}89 \\
82 \\
68 \\
108 \\
99 \\
96 \\
76\end{array}$ & $\begin{array}{l}252 \\
\\
226 \\
267 \\
290 \\
207 \\
250\end{array}$ & $\begin{array}{l}228 \\
204 \\
172 \\
190 \\
234 \\
183 \\
224\end{array}$ & $\begin{array}{l}204 \\
188 \\
159 \\
117 \\
189 \\
188\end{array}$ & $\begin{array}{l}174 \\
164 \\
125 \\
128 \\
148 \\
146 \\
160\end{array}$ & $\begin{array}{l}153 \\
155 \\
106 \\
105 \\
124 \\
124 \\
142\end{array}$ & $\begin{array}{r}132 \\
148 \\
70 \\
81 \\
90 \\
104 \\
126\end{array}$ & $\begin{array}{r}104 \\
144 \\
70\end{array}$ & $\begin{array}{l}27 \\
46 \\
18 \\
14 \\
15 \\
21 \\
27\end{array}$ & $\begin{array}{l}2.57 \\
1.51 \\
3.85 \\
4.95 \\
4.62 \\
3.30 \\
2.57\end{array}$ \\
\hline \multirow[t]{2}{*}{$\begin{array}{l}524 \\
\pm 83.4\end{array}$} & $\begin{array}{r}88.3 \\
\pm 5.2\end{array}$ & $\begin{array}{l}249 \\
\pm 12.0\end{array}$ & $\begin{array}{l}205 \\
\pm 9.2\end{array}$ & $\begin{array}{c}174 \\
\pm 12.9\end{array}$ & $\begin{array}{l}149 \\
\pm 6.9\end{array}$ & $\begin{array}{l}130 \\
+7.8\end{array}$ & $\begin{array}{c}107 \\
\pm 10.9\end{array}$ & $\begin{array}{l}102 \\
\pm 12.1\end{array}$ & $\begin{array}{r}24.0 \\
\pm 4.2\end{array}$ & $\begin{array}{r}2.89 \\
\pm 0.52\end{array}$ \\
\hline & \multicolumn{10}{|c|}{120 Minutes After $\mathrm{HGH}$} \\
\hline $\begin{array}{r}1,205 \\
1,403 \\
1,401 \\
1,199 \\
1,358 \\
872\end{array}$ & $\begin{array}{r}110 \\
100 \\
68 \\
81 \\
88 \\
94\end{array}$ & $\begin{array}{l}263 \\
226 \\
254 \\
269 \\
232 \\
238\end{array}$ & $\begin{array}{l}246 \\
214 \\
228 \\
228 \\
207 \\
204\end{array}$ & $\begin{array}{l}240 \\
204 \\
204 \\
201 \\
196 \\
176\end{array}$ & $\begin{array}{l}232 \\
200 \\
198 \\
183 \\
190 \\
162\end{array}$ & $\begin{array}{l}215 \\
106 \\
176 \\
172 \\
170 \\
150\end{array}$ & $\begin{array}{l}210 \\
188 \\
168 \\
155 \\
154 \\
136\end{array}$ & $\begin{array}{l}198 \\
184 \\
144 \\
125 \\
146 \\
124\end{array}$ & $\begin{array}{r}82 \\
120 \\
42 \\
31 \\
50 \\
38\end{array}$ & $\begin{array}{l}0.84 \\
0.58 \\
1.65 \\
2.24 \\
1.38 \\
1.82\end{array}$ \\
\hline $\begin{array}{l}1,240 \\
\pm 82.6\end{array}$ & $\begin{array}{r}90.2 \\
\pm 6.0\end{array}$ & $\begin{array}{l}247 \\
\pm 7.2\end{array}$ & $\begin{array}{l}221 \\
\pm 6.5\end{array}$ & $\begin{array}{l}204 \\
\pm 8.5\end{array}$ & $\begin{array}{l}194 \\
\pm 9.4\end{array}$ & $\begin{array}{l}180 \\
\pm 9.2\end{array}$ & $\begin{array}{c}169 \\
\pm 10.9\end{array}$ & $\begin{array}{c}154 \\
\pm 12.6\end{array}$ & $\begin{array}{r}60.5 \\
\pm 13.9\end{array}$ & $\begin{array}{r}1.15 \\
\pm 0.28\end{array}$ \\
\hline
\end{tabular}

ceptor, e.g., albumin, was added to the incubation medium to keep the intracellular fatty acid concentration low (32). Several recent studies have further indicated that it is not the fatty acids per se but rather the fatty acid acyl CoA derivatives that are directly responsible for the changes in enzyme activities resulting in the alterations in carbohydrate and lipid metabolism seen in conditions characterized by high plasma fatty acid levels (35-37).

\section{Summary}

A simple method has been described for producing an acute and sustained elevation of the plasma nonesterified fatty acid (NEFA) level. The results of this study indicate that in man an elevation in plasma NEFA concentration may be associated with an impaired glucose tolerance and decreased target organ sensitivity to insulin. The degree of impairment in carbohydrate tolerance is closely correlated with the elevation in the plasma NEFA level. After growth hormone administration the rise in plasma NEFA is temporally related to the appearance of insulin antagonism. These studies support the concept that several of the abnormalities of carbohydrate metabolism as- sociated with growth hormone administration, starvation, pregnancy, obesity, and diabetes mellitus may be a consequence, at least in part, of the elevated nonesterified fatty acid levels characteristic of these conditions.

\section{Acknowledgments}

We are grateful to Norman Cothran, Kathleen Keithly, and George Littleton for their technical assistance.

\section{References}

1. Dole, V. P. A relation between non-esterified fatty acids in plasma and the metabolism of glucose. J. clin. Invest. 1956, 35, 150.

2. Gordon, R. S., Jr., and A. Cherkes. Unesterified fatty acid in human blood plasma. J. clin. Invest. 1956, 35, 206.

3. Hales, C. N., and P. J. Randle. Effects of low-carbohydrate diet and diabetes mellitus on plasma concentrations of glucose, non-esterified fatty acid and insulin during oral glucose-tolerance tests. Lancet 1963, 1, 790.

4. Rabinowitz, D., and K. L. Zierler. Forearm metabolism in obesity and its response to intra-arterial insulin. Characterization of insulin resistance and evidence for adaptive hyperinsulinism. J. clin. Invest. 1962, 41, 2173.

5. Karam, J. H., G. M. Grodsky, and P. H. Forsham. Excessive insulin response to glucose in obese sub- 
jects as measured by immunochemical assay. Diabetes 1963, 12, 197.

6. Beck, P., J. H. T. Koumans, C. A. Winterling, M. F. Stein, W. H. Daughaday, and D. M. Kipnis. Studies of insulin and growth hormone secretion in human obesity. J. Lab. clin. Med. 1964, 64, 654.

7. Bierman, E. L., V. P. Dole, and T. N. Roberts. An abnormality of nonesterified fatty acid metabolism in diabetes mellitus. Diabetes 1957, 6, 475.

8. Andres, R., and K. L. Zierler. Spontaneous and insulin-induced resistance of peripheral tissues to insulin in diabetes. Clin. Res. 1958, 6, 250.

9. Yalow, R. S., and S. A. Berson. Immunoassay of endogenous plasma insulin in man. J. clin. Invest. 1960, 39, 1157.

10. Galbraith, H.-J. B., J. Ginsberg, and A. Paton. Decreased response to intra-arterial insulin in acromegaly. Diabetes 1960, 9, 459.

11. Rabinowitz, D., and K. L. Zierler. A metabolic regulating device based on the actions of human growth hormone and of insulin, singly and together, on the human forearm. Nature (Lond.) 1963, 199, 913.

12. Spellacy, W. N., and F. C. Goetz. Plasma insulin in normal late pregnancy. New Engl. J. Med. 1963, 268, 988.

13. Kalkhoff, R., D. S. Schalch, J. L. Walker, P. Beck, D. M. Kipnis, and W. H. Daughaday. Diabetogenic factors associated with pregnancy. Trans. Ass. Amer. Phycns 1964, 77, 270.

14. Raben, M. S., and C. H. Hollenberg. Effect of growth hormone on plasma fatty acids. J. clin. Invest. 1959, 38, 484.

15. Ikkos, D., R. Luft, C-A. Gemzell, and S. Almqvist. Effect of human growth hormone on glucose tolerance and some intermediary metabolites in man. Studies in healthy subjects given human growth hormone and in patients with acromegaly. Acta endocr. (Kbh.) 1962, 39, 547.

16. Stein, M. F., D. M. Kipnis, and W. H. Daughaday. The effect of human growth hormone on plasma insulin dynamics in man (abstract). J. Lab. clin. Med. 1962, 60, 1022.

17. Zierler, K. L., and D. Rabinowitz. Roles of insulin and growth hormone, based on studies of forearm metabolism in man. Medicine (Baltimore) 1963, 42, 385.

18. Randle, P. J., P. B. Garland, C. N. Hales, and E. A. Newsholme. The glucose fatty-acid cycle. Its role in insulin sensitivity and the metabolic disturbances of diabetes mellitus. Lancet 1963, 1, 785.

19. Shipp, J. C., L. H. Opie, and D. Challoner. Fatty acid and glucose metabolism in the perfused heart. Nature (Lond.) 1961, 189, 1018.

20. Williamson, J. R., and H. A. Krebs. Acetoacetate as fuel of respiration in the perfused rat heart. Biochem. J. 1961, 80, 540.

21. Garland, P: B., E. A. Newsholme, and P. J. Randle. Effect of fatty acids, ketone bodies, diabetes and starvation on pyruvate metabolism in rat heart and diaphragm muscle. Nature (Lond.) 1962, 195, 381.

22. Bowman, R. H. The effect of long-chain fatty acids on glucose utilization in the isolated perfused rat heart. Biochem. J. 1962, 84, 14p.

23. Moreton, J. R. Chylomicronemia, fat tolefance and atherosclerosis. J. Lab. clin. Med. 1950, 35, 373.

24. Korn, E. D. Clearing factor, a heparin-activated lipoprotein lipase. II. Substrate specificity and activation of cocoanut oil. J. biol. Chem. 1955, 215, 15.

25. Robinson, D. S., and P. M. Harris. The production of lipolytic activity in the circulation of the hind limb in response to heparin. Quart. J. exp. Physiol. 1959, 44, 80.

26. Fajans, S. S., and J. W. Conn. An approach to the prediction of diabetes mellitus by modification of the glucose tolerance test with ccrtisone. Diabetes 1954, 3, 296.

27. Silverstone, F. A., M. Brandfonbrener, N. W. Shock, and M. J. Yiengst. Age differences in the intravenous glucose tolerance tests and the response to insulin. J. clin. Invest. 1957, 36, 504.

28. Duncombe, W. G. The colorimetric micro-determination of long-chain fatty acids. Biochem. J. 1963, 88, 7.

29. Bernfeld, P., and T. F. Kelley. Inhibitory and activating effects of polyanions on lipoprotein lipase. J. biol. Chem. 1963, 238, 1236.

30. Morgan, C. R., and A. Lazarow. Immunoassay of insulin: two antibody system. Diabetes 1963, 12, 115.

31. Schalch, D. S., and M. L. Parker. A sensitive double antibody immunoassay for human growth hormone in plasma. Nature (Lond.) 1964, 203, 1141.

32. Leboeuf, B., and G. F. Cahill, Jr. Studies on rat adipose tissue in vitro. VIII. Effect of preparations of pituitary adrenocorticotropic and growth hormones on glucose metabolism. J. biol. Chem. 1961, 236, 41.

33. Werk, E. E., Jr., H. T. McPherson, L. W. Hamrick, Jr., J. D. Meyers, and F. L. Engel. Studies on ketone metabolism in man. I. A method for the quantitative estimation of splanchnic ketone production. J. clin. Invest. 1955, 34, 1256.

34. Verner, J. V., Jr., W. G. Blackard, and F. L. Engel. Some factors modifying the actions of hormones on glucose uptake by adipose tissue in vitro. Endocrinology 1962, 70, 420.

35. Wieland, O., and L. Weiss. Inhibition of citrate-synthase by palmityl-coenzyme A. Biochem. biophys. Res. Commun. 1963, 13, 26.

36. Bortz, W. M., and F. Lynen. The inhibition of acetyl CoA carboxylase by long chain acyl CoA derivatives. Biochem. Z. 1963, 337, 505.

37. Tubbs, P. K. Inhibition of citrate formation by longchain acyl thioesters of coenzyme $A$ as a possible control mechanism in fatty acid biosynthesis. Biochim. biophys. Acta (Amst.) 1963, 70, 608. 